\title{
CHILD-CENTERED APPROACH TO TEACHING AS A HOLISTIC CATEGORY
}

\author{
Tetiana Konovalenko, Maxim Rutkovsky \\ Melitopol Bohdan Khmelnitsky State Pedagogical University
}

\begin{abstract}
Resume:
The article is devoted to the theoretical principles of childcentered education as it is discussed abroad. The issue is analysed as a holistic category. Reconceptualists and poststructuralists increasingly criticize child-centered pedagogy as being overly reliant on outmoded notions of (developmentally appropriate) practices. Reconceptualists believe that developmental theories should be critically examined cross culturally, whereas poststructuralists work from a social perspective to reconstruct views of a child based on his or her multiple meaning making and discourse. This article shows that the tenor of following a child's lead is a product of three paradigms (childcenteredness, reconceptualism and poststructuralism) and differences in the scopes of understanding of a child and his or her acts of inquiry. Incorporating these paradigms can develop child-centeredness with an expanded scope of view-from the micro layer of schooling to the meso layer of community and to the macro layer of society- and by exacting acts of applying, revising and restructuring. Such a synthesis would result in a deeper understanding of a child's optimal learning and in a broadening of the purpose of pedagogy at the macrosocial level.
\end{abstract}

Key words:

child-centeredness; child-centered education; diversity; equity; poststructuralism; reconceptualism.
Анотація:

Коноваленко Тетяна, Рутковський

Максим. Дитиноцентрований підхід до навчання як цілісна категорія.

Статтю присвячено аналізу обговорення теоретичних засад дитиноцентрованого навчання з погляду закордонних учених. Проблему проаналізовано як цілісну категорію. Показано, що концептуалісти та постструктуралісти все частіше критикують орієнтовану на дитину педагогіку, оскільки вона надмірно покладається на застарілі уявлення про розвивальну практичну діяльність Реконцептуалісти вважають, що теорії розвитку слід критично досліджувати міжкультурно, тоді як постструктуралісти розглядають це з соціальної позиції, щоб реконструювати погляди на дитиноцентрованість на основі її численних значень та дискурсу. У статті доведено, що принцип дитиноцентрованості $є$ продуктом трьох парадигм (орієнтованість на дитину, реконцептуалізм та постструктуралізм) і відмінностей у розумінні дитини та її поведінки. Урахування цих парадигм може розвинути орієнтованість на дитину з більш широких позицій - від мікрошару шкільного навчання до мезошару громади та макрорівня суспільства, застосовуючи для цього перегляд і реструктуризацію. Такий синтез сприятиме глибшому розумінню оптимального навчання дитини та розширенню цілей педагогіки на макросоціальному рівні.

Ключові слова:

дитиноцентрованість

дитиноцентрована

різноманітність;

постструктуралізм; реконцептуалізм.

\begin{abstract}
Аннотация:
Коноваленко Татьяна, Рутковский Максим. Личностно ориентированное обучение детей как целостная категория. Статья посвящена анализу обсуждения теоретических основ личностно ориентированного обучения детей с точки зрения зарубежных ученых. Проблема анализируется как целостная категория. Показано, что реконцептуалисты и постструктуралисты все чаще критикуют ориентированную на ребенка педагогику, поскольку она чрезмерно полагается на устаревшие представления о развивающей практической деятельности. Реконцептуалисты считают, что теорию развития следует критически исследовать межкультурно, тогда как постструктуралисты рассматривают это с социальной точки зрения, чтобы реконструировать взгляды на личностно-ориентированное обучение детей на основе его многочисленных значений и дискурса. В статье доказывается, что принцип личностно ориентированного обучения детей является продуктом трех парадигм (ориентированность на ребенка, реконцептуализм и постструктурализм) и различий в понимании ребенка и его поведения. Учет этих парадигм может развить ориентированность на ребенка с более широких позиций - от микросистемы школьного обучения до мезосистемы общины и макроуровня общества, используя для этого пересмотр и реструктуризацию. Такой синтез будет способствовать более глубокому пониманию оптимального обучения ребенка и расширению целей педагогики на макросоциальном уровне.
\end{abstract}

\section{Ключевые слова:}

ориентированность на ребенка; личностно ориентированное разнообразие; обучение

детей; постструктурализм; реконцептуализм.
Setting of the problem. The issue of childcentered teaching was discussed by foreign researchers from the point of view of social and philosophic categories. Reconceptualist and poststructuralist theorists have influenced teachers' views of child-centeredness, diversity, and equity. The construct of child-centeredness has dominated early childhood education for the past few decades, especially in the form of developmentally appropriate practices. However, reconceptualists and poststructuralists emphasize diversity. In particular, they have expressed concern that developmentally appropriate practices are biased on Western theories of child development and has limited application with respect to education social and cultural dimensions $[5 ; 6 ; 11]$.
For the reason that education takes place within society's ever-changing, increasingly global contexts, it is important to view education from a holistic perspective [1]. With regard to early childhood education, we advocate a concept of childcenteredness that incorporates reconceptualist and poststructuralist notions of diversity and equity.

However, because the terms diversity and equity have been popularly used in the field of education in general, in light of the surging critical movement, here we focus on pedagogical elaboration in early childhood educationby drawing on various related scholarly works [11]. In both early childhood educationand general education, diversity and equity have been examined by attending to the issues of inequity between the dominant and the oppressed through drawing on the theoretical lens of 
power [10]. No matter what the field of education (including early childhood education), various applications have reconceptualized a wide array of issues, such as gender, race, socioeconomic status and culture, in relation to policy, teacher education, choices of contentknowledge and school practice. Here we focus on the use of the terms equity and diversity in opposition to the standardized principles of early childhood education, including developmentally appropriate practicesand Western theories of child development. By synthesizing a number of scholars' works, we integrate these two terms into the concept of child-centeredness [2]

This incorporation is based on the understanding that any theory of education has limited utility [8]. Dewey argued that education should integrate multiple theories to accommodate a variety of learning situations. Effective education requires constant reassessment and adjustment that take multiple elements into account [8]. In keeping with Dewey's view, reconceptualists and poststructuralists seek to synthesize different concepts and approaches rather than treat them as separate and irreconcilable [3]. Such theorists advocate combining the notion of child-centeredness with principles of equity and diversity in order to achieve a more holistic approach to education. It is hard to operationalize equity and diversity. These constructs have yet to be adequately analyzed in terms of best practice [11]. Nevertheless, a synthesis of the principles of child- centeredness, equity and diversity can serve as a foundation for early childhood education.

The philosophies of Rousseau and Pestalozzi included the view that early education should be child-centered [9]. Froebel is believed to have coined the term "child-centered", which appeared in his 1826 book "The education of man", and it has been prominent in education literature ever since [7]. For many years, child-centeredness has dominated discourse about best practice in early childhood education [4]. In contrast to a traditional didactic approach to pedagogy, a child-centered approach stresses the child's autonomy and ability to construct knowledge rather than knowledge as something imparted by the teacher as authority [5]. In addition, whereas traditional pedagogy is linear and subjectdriven, child-centered pedagogy focuses on children's needs and interests.

Chung and Walsh conducted a comprehensive review of contemporary literature on early childhood education and found more than forty definitions of child-centeredness to be in use. It is, therefore, not surprising that educators differ in the theories and approaches that they regard as child- centered. Influenced by such prominent child- development theorists as Piaget and Vygotsky, some educators believe that child-centered education focuses on a child's developmental needs. Other educators consider "child-centered" in terms of Dewey's philosophy of education, which emphasizes progressive forms of education [14].

Since 1987 the National Association for the Education of Young Children (NAEYC) has emphasized a child-centered approach based on developmentally appropriate practices [15]. The NAEYC has provided developmentally appropriate practicesguidelines for teaching children eight years old or younger [14]. According to the NAEYC, pedagogical decisions that result in developmentally appropriate practicesare based on adequate knowledge of each of the following: "child development and learning," each child's "strengths, interests and needs," and "the social and cultural contexts in which children live" [3]. However, many teachers are uncertain as to how to provide DAP [10].

Reconceptualists believe that a standard child development approach to child-centeredness is limited, partly because the theory underlying this approach developed only in the West and primarily before 80 's. In their view, knowledge should continually be reconstructed across a variety of individuals, cultures and contexts. For example, Graue has remarked that the hegemony of the developmental perspective has discouraged adequate sensitivity and attention to sociocultural differences among children. Reconceptualists urge a holistic view of children's developmental needs that encompasses sociocultural as well as biological factors [5]. In a reconceptualist approach, the teacher interacts with each student to discover that child's unique needs rather than simply employs standardized practices $[5 ; 6 ;]$. MacNaughton has argued that the developmentally appropriate practicesapproach can create inequity by neglecting social relationships within the classroom, failing to value knowledge derived from actual classroom practices, and relying on outdated theories of child development [14]. Reconceptualists see teachers as scholars who continually revise their theories of education as well as their pedagogy based on what they discover in the classroom [15].

Our use of poststructuralism in this paper serves to highlight the particular observation made by a number of scholars [15] that through multiple discourses, knowledge can be perceived differently and turned into various ways of thinking and knowing. Poststructuralism emphasizes, through discourses across time (such as teachers' autobiographies) and place (such as the "funds of knowledge" studies byGonzález et al., the richer thinking and knowing by which a child's development and learning occur [12]. Through discourses, poststructuralism is sensitive to the equity of diverse ethnic/racial, cultural and social contexts [14]. It emphasizes education as spanning 
different times and places [12]. In particular, poststructuralismcalls for attention to and voicing of underrepresented perspectives [11].

Teachers who employ a poststructuralist approach often engage in autobiography and use other forms of self-examination to gain a deeper understanding of their own teaching [11]. In the classroom, they use children's real-life experiences to foster literacy [12]. Poststructuralist teachers also heavily rely on children's artistic creations. For example, the Reggio Emilia approach encourages children to give artistic expression to their unique perspectives [9]. In creating art, children create multiple discourses that result in each child's meaning-making being valued.

In Stockholm, it has implemented a project that exemplifies education as an encompassing of diversity [11]. The Stockholm Project in Sweden manifests community networking as a way to embrace diversity through delivering practices and educational services across institutions such as schools, homes and community spaces with multiple dialogues among teachers, paraprofessionals, parents and children, the project promotes "a more multivoiced and multi-centered discourse," with fair consideration in constructing the quality of early childhood practices [11].

The international Netpal project supports intercultural communication and meaning-making among U.S. and Taiwanese kindergartners [7] with their teacher's assistance, the children communicate their life experiences by drawing and by writing in their native language [7]. Such poststructuralist educational projects foster learning through the sharing of discourses that represent different histories, cultures, politics, and other contexts involved in the construction of knowledge.

Poststructuralists challenge the view that knowledge is obtained strictly by scientific methods or imparted by those in power. They see knowledge as constructed by all participants, whose perspectives have equal value and who contribute their own unique discourses, which change in response to factors such as culture, time and place.

Our intention here is to integrate childcenteredness,reconceptualism and poststructuralism to sustain educational development in a changing context of globalization. The United Nations (20052014) has been dedicated to the 10-year movement of education for sustainable development. A number of scholars (Jucker, 2004; Siraj-Blatchford, 2009) elaborated that education for sustainable development. has to be made by integrating values, principles and practices to respond to both the current demands and future prospects of society. Moreover, scholars who have studied ways to cope with volatile global changes [8] have also addressed that the "only" perspective may tear the world apart by using fragmentation to deal with complexity. Those scholars stated their position, in line with Dewey, to remind us that any single approach may break down collaboration and move us toward "unsustainability" [8].

In addition, Kauffman's reflexive theory and Fuchs's systematic thinking also validated the interlocking relationships among theories, perspectives and ways of thinking. They address that the world comprises a number of theories, and each is reflexive in nature (to complement deficiencies and move further) to enhance our comprehension of reality. The ultimate purpose is to incorporate each theory [4].

Various methods of integration have been proposed by a number of early childhood educationscholars to push forward theoretical development. For example, Graue connected the three domains of early childhood educationstudies to sustain teachers' professional development: developmental realism, critical realism and practical realism. Peter and Blatchford integrated theories by broadening the concept of postmodernism with the necessity of opening up to and integrating others in sustaining theoretical development. Siraj-Blatchford believed that the narrow view of postmodernism under which it prevails on others to abdicate others might itself operate under the fallacy of hegemony by neglecting others. However, although these integrated efforts have been merged, efforts still fall short of reaching a true vision to afford integration and amend child-centered teaching. Here we aim to close this gap by providing a conceptual vision with classroom suggestions for incorporating childcenteredness with reconceptualism and poststructuralism.

Regardless of the varied disputes associated with the construct of child-centredness, the philosophical tenor of focusing on and following a child's lead is a product of child-centeredness, reconceptualism and postmodernism. Child-centeredness understands children's needs byapplying child development theories, whereas reconceptualists critically analyze a child's development and learning across various cultures. In contrast, poststructuralists inquire about various social discourses relating to the wide-ranging possible views of a child [8].

In other words, the preceding three paradigms can be incorporated to broaden the scope with which one can view a child. Analogically to Bronfenbrenner's ecological theory, reconceptualists broaden their scope of view from the micro layer of development in the school context to the meso layer of community outreach. Poststructuralits further extend their scope to the macro layer, which has a larger sociocultural context with which to investigate various social dynamics (for example, policies, globalization and societal changes) relating to a child's growth and doing. In addition, acts of inquiry are different but are 
graded across the three layers first by understanding and applying developmental theories and then by rethinking, revising and reconstructing the theories, if necessary [11].

The reflective questions and suggestions presented below have been provided as examples of incorporating for teachers and educators to reconceptualize children's development and learning, and to reconstruct new possibilities.

- How can children's development be perceived in a holistic way, encompassing macro-socio-cultural perspectives, in addition to developmental theories?

- How can the multiplicities of children's development and learning be reconceptualized in order to encourage rather than prohibit teachers in uncovering unknown possibilities?

Suggestions drawn from reconceptualism: Viewing classroom practices as the scholarship activity of reconceptualizing and theorizing knowledge.

Suggestions drawn from poststructuralism: Take an equal account of each child's meaning-making, a different process in different cultures and families, in order to make multiple discourses across institutions (such as the practices of "funds of knowledge", facilitation of multicentered discourse by Stockholm and intercultural communication by Netpal project).

How can teachers interact with children as a way to uncover the unknown truth embedded in education rather than to standardize practices and negate complicated sociocultural factors?

Suggestion drawn upon reconceptualism: Emphasize teachers' reflective thinking as a continual way to know children.

Suggestion drawn upon poststructuralism: Explore the multiple meanings behind the language and actions from multiple discourses across time and places (such as a teacher's autobiography and classroom narrative inquiry).

Conclusion. Historically, pedagogical theory and practice have progressed from a didactic, teachercentered approach to a child-centered approach in which the child creates meaning with the surging critical movement, reconceptualists believe that child-centered education should not be limited to developmentally appropriate practices based on traditional Western theories of child development but should continually be reassessed and reconstructed. As part of this continual revision, teachers continually examine their own theories and practices. Recent efforts to reconstruct an equitable outlook, poststructuralists advocate that this continual reconceptualizing be based on diverse perspectives and that it entail particular attention to underrepresented voices. Ultimately, the goal is to facilitate the adoption of these multiple discourses across schools, communities and societies to broaden our scope of understanding and add depth to the possible ways in which we can view children.

We support incorporating reconceptualism and poststructuralism into child-centered education to broaden the scope of vision of a child from the micro layer to meso and macro layers. Furthermore, we believe that, we can foster such incorporation by basing early childhood education on both developmental and sociocultural significancies across school, community and societal contexts. As Graue has noted, a synthesis of diverse paradigms and perspectives will result in richer, more holistic childhood education. Such a synthesis will help to ensure equity, diversity and maximal learning.

\section{References}

1. Astafurova T. N. Strategies of communicative behavior in professionally significant situations of intercultural communication. https://www.twirpx.com/file/1121061/ [in Russian].

2. Kochetkov V. V. (2002). The psychology of cross-cultural differences. Moscow: Modern Education [in Russian].

3. Likhachev D. S. (1996). Essays on the philosophy of artistic creativity. SPb.: BLITS [in Russian].

4. Ter-Minasova S. G. (2008). Language and intercultural communication. Moscow: Slovo. [in Russian].

5. Burman E. (1996). Deconstructing developmental psychology. Routledge, London [in English].

6. Cannella G. (2000). Critical and feministre constructions of early childhood education: Continuing the conversation. Contemp. Issues Early Child., 1: 215-220 [in English].

7. Chung S, Walsh D. J (2000). Unpackingchild-centredness: A history of meanings. Curric. Stud., 32: 215-234 [in English].

8. Dewey J. (1998). Experience and education, Kappa Delta Pi, West Lafayette, IN [in English].

9. Essa E. L. (1999). Introduction to early childhood education (3rd ed). Delmar, Albany, NY [in English].

10. Foucault M. (1980). Pwer-knowledge: Selected interviews and other writings, 1972-1977. Harvester, Brighton, UK [in English].

\section{Список використаних джерел}

1. Астафурова Т. Н. Стратегии коммуникативного поведения в профессионально-значимых ситуаціях межкультурного общения. URL: https://www.twirpx.com/file/1121061 (дата звернення: 23.05.2020)

2. Кочетков В. В. Психология межкультурных различий. Москва: Современное образование, 2002. 416 с.

3. Лихачев Д. С. Очерки по философии художественного творчества. Санкт-Петербург: БЛИЦ, 1996. 159 с.

4. Тер-Минасова С. Г. Язык и межкультурная коммуникация. Москва: Слово, 2008. 352 с.

5. Burman E. Deconstructing developmental psychology. Routledge, London, 1996.

6. Cannella G. Critical and feministre constructions of early childhood education: Continuing the conversation. Contemp. Issues Early Child. 2000. № 1. PP. 215-220.

7. Chung S, Walsh D.J. Unpackingchild-centredness: A history of meanings. Curric. Stud., 32: 215-234.

8. Dewey J. Experience and education, Kappa Delta Pi, West Lafayette, IN, 1998.

9. Essa E. L. Introduction to early childhood education (3rd ed). Delmar, Albany, NY, 1998.

10. Foucault M. Pwer-knowledge: Selected interviews and other writings, 1972-1977. Harvester, Brighton, UK, 1980. 
11. Genishi C., Ryan S., Ochsner M., Yarnall M. (2001). Teaching in early childhood education: Understanding practice sthrough research and theory. In Richardson V (ed). Handbook of research on teaching, American Educational Research Association, Washington, DC., PP. 1175-1210 [in English].

12. González N., Moll L., Amanti C. (2005). Funds of knowledge: Theorizing practices in households, communities, and classrooms. Lawrence Erlbaum Associates, Mahwah, NJ. [in English].

13. Grieshaber S., Ryan S. (2005). Transforming ideas and in: Grieshaber S, Ryan S (eds). Practical transformational and transformative globalization, post-modernism, and early childhood education, Elsevier, Oxford, PP. 3-16 [in English].

14. MacNaughton G. (2001). Rethinking gender in early childhood education, Sage, London [in English].

15. Popkewitz T. S. (2003). Governing the child. In: Bloch MN, Holmlund K, Moqvist I, Popkewitz T. S. (eds). Governing children, families, andeducation: Restructuring the welfare state. Macmillan, NewYork, PP. 35-62 [in English].

Information about the authors: KonovalenkoTetianaVasylivna angl_fil_mdpu@ukr.net Bohdan Khmelnytsky Melitopol State Pedagogical University 20 Hetmans'ka St., Melitopol, Zaporizhzhia region, 72312, Ukraine

Rutkovsky Maxim Sergiyovych angl_fil_mdpu@ukr.net Bohdan Khmelnytsky Melitopol State Pedagogical University 20 Hetmans'ka St., Melitopol, Zaporizhzhia region, 72312, Ukraine doi: $10.33842 / 22195203 / 2021 / 25 / 16 / 20$

Received at the editorial office 10. 12. 2020. Accepted for publishing 21. 12. 2020.
11. Genishi C., Ryan S., Ochsner M., Yarnall M. Teaching in early childhood education: Understanding practice sthrough research and theory. In Richardson V (ed). Handbook of research on teaching, American Educational Research Association, Washington, DC, 2001. PP. 11751210.

12. González N., Moll L., Amanti C. Funds of knowledge: Theorizing practices in households, communities, and classrooms. Lawrence Erlbaum Associates, Mahwah, NJ, 2005.

13. Grieshaber S., Ryan S. Transforming ideas and in: Grieshaber S, Ryan S (eds). Practical transformational and transformative globalization, post-modernism, and early childhood education, Elsevier, Oxford, 2005. PP. 3-16.

14. MacNaughton G. Rethinking gender in early childhood education, Sage, London, 2001.

15. Popkewitz T. S. Governing the child. In: Bloch MN, Holmlund K, Moqvist I, Popkewitz T. S. (eds). Governing children, families, andeducation: Restructuring the welfare state. Macmillan, NewYork, 2003. PP. 35-62.

\section{Відомості про авторів: Коноваленко Тетяна Василівна angl_fil_mdpu@ukr.net} Мелітопольський державний педагогічний університет імені Богдана Хмельницького вул. Гетьманська, 20, м. Мелітополь, Запорізька обл., 72312, Україна

Рутковський Максим Сергійович angl_fil_mdpu@ukr.net Мелітопольський державний педагогічний університет імені Богдана Хмельницького вул. Гетьманська, 20, м. Мелітополь, Запорізька обл., 72312, Україна

doi: $10.33842 / 22195203 / 2021 / 25 / 16 / 20$

Матеріал надійшов до редакиії 10. 12. 2020 р. Прийнято до друку 21. 12. 2020 p. 